\title{
PENGARUH SISTEM PENGENDALIAN INTERN DAN SISTEM AKUNTANSI KEUANGAN DAERAH TERHADAP KUALITAS LAPORAN KEUANGAN PEMERINTAH
}

\author{
Novtania Mokoginta ${ }^{1}$, Linda Lambey ${ }^{2}$, Winston Pontoh $^{3}$ \\ ${ }^{1,2,3}$ Fakultas Ekonomi dan Bisnis, Jurusan Akuntansi, Universitas Sam Ratulangi, Jl. Kampus Bahu, Manado, \\ 95115, Indonesia
}

E-mail : taniamokoginta@gmail.com

\begin{abstract}
Application of Internal Control System and Regional Financial Accounting System in management of local government financial statements is a very important thing. This financial statements of local governments must meet the following characteristics : relevant, reliable, comparable, and understandable. The purpose this study to examine the influence of the Internal Control System, Regional Financial Accounting System on the quality of goverment financial statements. The population in this study are all working in BPKAD Bolaang Mongondow Utara. The sample in this study is the staff / employees of the financial part of the respondents were 30 respondents. The samples were selected by using a purposive samplingmethod. Data was collected by distributing questionnaires to the respondents directly concerned. Technical analysis of the data used is multiple regression with SPSS 22.

The result showed that : the Internal Control System has a significant effect on the quality of government financial statements and the Regional Financial Accounting System has a positive significant effect on the quality of goverment financial statements.
\end{abstract}

Keywords : Internal Control system, Regional finsncisl accaounting system, quality of goverment financial statements.

\section{PENDAHULUAN}

Di era reformasi pengelolaan keuangan daerah sudah mengalami berbagai perubahan regulasi dari waktu ke waktu. Perubahan tersebut merupakan rangkaian pemerintah agar dapat mewujudkan good govermance dan clean govermance. Penyusunan laporan keuangan yang berpedoman pada standar akuntansi pemerintah sesungguhnya adalah dalam rangka peningkatan kualitas laporan keuangan serta kinerja pemerintah, agar supaya laporan keuangan dan kinerja pemerintah yang dimaksud dapat mewujudkan transparansi dan akuntabilitas pengelolaan keuangan pemerintah daerah.

Pengendalian intern dalam suatu organisasi perusahaan, lembaga organisasi profit maupun nonprofit mutlak menjadi hal yang utama dan sangat dibutuhkan karena kegiatan oprasional dan kinerja memerlukan suatu kebijakan khusus yang mampu mengakomodasi dan memberikan batasan serta ketentuan khusus dalam setiap pelaksanaan kegiatannya. Pengendalian intern dibutuhkan agar mudah dalam menemukan atau menganalisis permasalahan-permasalahan yang ada atau permasalahan yang mungkin akan timbul dalam proses pencapaian tujuan sehingga pencapaian tujuan bisa kita ketahui secara jelas. Dalam meningkatkan kinerja pemerintah senantiasa menghadapi masalah yang kompleks, permasalahan yang paling umum terjadi ialah korupsi, kesalahan administrasi serta pengelolan keuangan yang tidak berjalan dengan baik.

Laporan Keuangan Pemerintah Daerah (LKPD) setiap tahunnya mendapat penilaian berupa opini dari Badan Pengawas Keuangan (BPK). Terdapat empat opini yang diberikan pemeriksa yaitu: Opini Wajar Tanpa Pengecualian (WTP), Opini Wajar Dengan Pengecualian (WDP), Opini Tidak Wajar (TP), dan Pernyataan Menolak memberi Opini atau Tidak Memberi Pendapat (TMP). 
Laporan keuangan merupakan wujud dari transparansi dan akuntabilitas suatu entitas serta media informasi akuntansi untuk bisa menyampaikan hasil kinerja pengelolaan keuangan kepada pihak lain. Menurut PP 71 tahun 2010 tentang Standar Akuntansi Pemerintah; Informasi dalam laporan keuangan pemerintah dikatakan berkualitas jika informasi tersebut memenuhi kriteria dalam akuntansi pemerintahan yaitu relevan (relevance), andal (reability), dapat dipahami (understandability) dan dapat di bandingkan (comparability).

Akuntansi keuangan daerah memegang peranan penting pengelolaan keuangan daerah agar dapat berjalan sebagaimana mestinya. Selama ini pelaporan keuangan pemerintah, baik di pusat maupun daerah terkesan belum memenuhi kebutuhan informasi pemakainya. Kurangnya informasi menyebabkan pemerintah tidak mempunyai manajerial yang baik. Berdasarkan hasil audit temuan Badan Pemerikasa Keuangan (BPK) pada tahun 2016 memberikan pendapat Wajar Dengan Pengecualian (WDP) terhadap laporan keuangan Pemerintah Kabupaten Bolaang Mongondow Utara, hal ini dikarenakan oleh lemahnya pengendalian intern, dan permasalahan-permasalahan yang dihadapi dalam rangka penyusunan dan penyajian Laporan Keuangan, yaitu antara lain : belum tersediannya tenaga akuntansi yang telah memiliki kompetensi dalam penyajian dan penyusunan Laporan Keuangan, pejabat pengelolola keuangan SKPD belum maksimal dalam memahami tugas dan fungsinya masing-masing, sehingga terjadi saling lempar tanggung jawab antara sesama pejabat pengelola keuangan SKPD. Masih rendahnya kualitas penyusunan laporan keuangan dan administrasi pengelolaan aset dimasing-masing SKPD. Tujuan dari penelitian ini adalah : (1) untuk mengetahui pengaruh Sistem Pengendalian Intern terhadap Kualitas Laporan Keuangan Pemerintah; (2) untuk mengetahui pengaruh Sistem Akuntansi Keuangan Daerah terhadap Kualitas Laporan Keuangan Pemerintah

\section{TINJAUAN PUSTAKA}

\subsection{Sistem Pengendalian Intern}

Sistem pengendalian internal meliputi struktur organisasi, metode dan ukuran-ukuran yang dikoordinasikan untuk menjaga kekayaan organisasi, mengecek ketelitian dan keandalan data akuntansi, mendorong efisiensi dan mendorong dipatuhinya kebijakan manajemen. Berdasarkan kedua pengertian di atas, dapat ditarik kesimpulan bahwa pengendalian internal adalah metode, proses, dan kebijakan yang didesain oleh dewan komisaris, manajemen dan personel lain untuk memberi jaminan yang memadai atas tercapainya efisiensi dan efektifitas operasi, keandalan laporan keuangan, dan kepatuhan terhadap hukum dan peraturan yang berlaku (Mulyadi, 2013:163). Sistem Pengendalian Internal Pemerintah (SPIP) menurut UU No. 60 Tahun 2008. Sistem Pengendalian Intern adalah proses yang integral pada tindakan dan kegiatan yang dilakukan secara terus menerus oleh pimpinan dan seluruh pegawai untuk memberikan kayakinan memadai atas tercapainya tujuan organisasi melalui kegiatan yang efektif dan efisien keandalan pelaporan keuangan, pengamanan aset negara, dan ketaatan terhadap peraturan perundang-undangan.

\subsubsection{Komponen-komponen Pengendalian Internal}

Menurut Committee of Sponsoring Organization of the Tread way Commission (COSO). Pengendalian Internal satuan usaha terdiri atas komponen-komponen berikut:

1) Lingkungan pengendalian

2) Penaksiran risiko

3) Informasi dan komunikasi

4) Aktivitas pengendalian

5) Pemantauan 
Sedangkan dalam PP No. 60 tahun 2008 tentang Sistem Pengendalian Intern Pemerintah, terdapat lima unsur dari pengendalian internal pemerintahan yaitu:

1. Pengendalian Lingkungan

2. Penilaian Resiko

3. Kegiatan Pengendalian

4. Informasi dan Komunikasi

5. Pemantauan Pengendalian Internal

\subsubsection{Tujuan Pengendalian Internal}

Menurut Mulyadi (2013:163), tujuan sistem pengendalian internal adalah:

1. Menjaga kekayaan organisasi

2. Mengecek ketelitian dan keandalan data akuntansi

3. Mendorong efisiensi, dan

4. Mendorong dipatuhinya kebijakan manajemen

\subsection{Pengertian Sistem Akuntansi Keuangan Daerah}

Menurut Halim (2012:35) akuntansi keuangan daerah dapat di definisikan sebagai berikut : "Suatu proses identifikasi, pengukuran, dan pelaporan transaksi ekonomi (keuangan) dari suatu daerah (Provinsi, kabupaten, Kota) yang dijadikan sebagai informasi dalam pengambilan keputusan ekonomi oleh pihak-pihak yang memerlukan”.

Dari pengertian di atas, maka dapat diambil kesimpulan bahwa Sistem Akuntansi Keuangan Daerah (SAKD) merupakan sistem akuntansi yang terdiri dari seperangkat kebijakan, standard dan prosedur yang dapat menghasilkan laporan yang relevan, andal dan tepat waktu untuk menghasilkan informasi dalam bentuk laporan keuangan yang akan digunakan oleh pihak intern dan ekstern pemerintah daerah untuk mengambil keputusan ekonomi. Sehingga dimensi dari Sistem Akuntansi Keuangan Daerah terdiri dari :

1. Kebijakan Sistem Akuntansi Keuangan Daerah (SAKD)

2. Prosedur Sistem Akuntansi Keuangan Daerah (SAKD)

3. Sistem Akuntansi Sumber Daya Manusia, dan

4. Sistem Teknologi Informasi.

\subsubsection{Prosedur Sistem Akuntansi Keuangan Daerah}

Halim, (2012: 84) Menjelaskan sistem akuntansi pemerintah daerah secara garis besar terdiri atas empat prosedur akuntansi yaitu akuntansi penerimaan kas, akuntansi pengeluaran kas, akuntasi selain kas, dan akuntansi asset, dan disempurnakan oleh permendagri menjadi 5 prosedur sistem akuntansi keuangan daerah yang meliputi sebagai berikut:

1. Prosedur Akuntansi Penerimaan Kas

Prosedur akuntansi penerimaan kas pada SKPKD adalah serangkaian proses mulai dari pencatatan, pengikhitisaran, sampai dengan pelaporan keuangan yang berkaitan dengan penerimaan kas dalam rangka pertanggungjawaban pelaksanaan APBD yang dapat dilakukan secara manual atau menggunakan aplikasi komputer.

2. Prosedur Akuntansi Pengeluaran Kas

Prosedur akuntansi pengeluaran kas adalah serangkaian proses, baik manual maupun terkomputerisasi, mulai dari pencatatan, penggolongan dan peringkasan transaksi atau kejadian keuangan, hingga pelaporan keuangan dalam rangka pertanggungjawaban pelaksanaan APBD yang berkaitan dengan pengeluaran kas pada SKPD dan/atau SKPKD

3. Prosedur Akuntansi Aset Tetap/Barang Milik Daerah

Prosedur akuntansi asset adalah serangkaian proses, baik manual maupun komputerisasi, mulai dari pencatatan dan pelaporan akuntansi atas perolehan, hingga pemeliharaan, rehabilitas, penghapusan, pemindah tanganan, perubahan klasifikasi dan penyusutan 
terhadap asset yang dikuasai/digunakan SKPD atau SKPKD. Prosedur akuntansi asset digunakan sebagai alat pengendali dalam pengelolan asset yang dikuasai/digunakan SKPD atau SKPKD.

4. Prosedur Akuntansi Selain Kas

Prosedur akuntansi selain kas adalah serangkaian proses mulai dari pencatatan, pengikhitisaran, sampai dengan pelaporan keuangan yang berkaitan dengan semua transaksi atau kejadian selain kas yang dapat dilakukan secara manual atau menggunakan aplikasi komputer

5. Penyajian Laporan Keuangan

Secara garis besar, tujuan umum penyajian laporan keuangan oleh pemerintah daerah adalah untuk memberikan informasi yang digunakan dalam pembuatan keputusan ekonomi, sosial dan politik serta sebagai bukti pertanggungjawaban dan pengelolaan.

\subsubsection{Sistem pencatatan}

Terdapat beberapa macam sistem pencatatan yang dapat digunakan, yaitu sistem pencatatan single entry, double entry, dan triple entry.

\section{a. Single Entry}

Berdasarkan Permendagri Nomor 13 Tahun 2006, sistem pencatatan single entry dilakukan oleh bendahara penerimaan dan bendahara pengeluaran baik di level SKPD maupun Satuan Kerja Pengelola Keuangan Daerah (SKPKD). Sistem ini hanya sebagai alat kontrol sistem akuntansi yang sebenarnya yang dilakukan oleh Pejabat Pengelola Keuangan SKPD (PPK SKPD) dan oleh Bendahara Umum Daerah (BUD).

\section{b. Double Entry}

Sistem pencatatan double entry Sering juga disebut sebagai sistem tata buku berpasangan. Menurut sistem ini, pada dasarnya suatu transaksi ekonomi akan dicatat dua kali. Pencatatan dengan sistem ini disebut dengan istilah menjurnal. Persamaan dasar akuntansi tersebut berbentuk sebagai berikut:

\section{AKTIVA + BELANJA = UTANG + EKUITAS DANA + PENDAPATAN}

Transaksi yang berakibat bertambahnya aktiva akan dicatat pada sisi debit sedangkan yang berakibat berkurangnya aktiva akan dicatat pada sisi kredit. Hal yang sama dilakukan untuk mencatat belanja. Hal yang sebaliknya dilakukan untuk utang, ekuitas dana, dan pendapatan. Apabila suatu transaksi mengakibatkan bertambahnya utang, maka pencatatan akan dilakukan pada sisi kredit, sedangkan jika mengakibatkan berkurangnya utang, maka pencatatan dilakukan pada sisi debit. Hal serupa ini dilakukan untuk ekuitas dana dan pendapatan.

\section{c. Triple Entry}

Sistem pencatatan triple entry adalah pelaksanaan pencatatan dengan menggunakan sistem pencatatan double entry, ditambah dengan pencatatan pada buku anggaran.

Komponen Laporan Keuangan berdasarkan PP 71 tahun 2010 yaitu:

1. Laporan Realisasi Anggaran

2. Laporan Perubahan Saldo Anggaran Lebih (SAL)

3. Neraca

4. Laporan Arus Kas

5. Laporan Operasional

6. Laporan Perubahan Ekuitas

7. Catatan atas Laporan Keuangan 


\subsection{Kualitas Laporan Keuangan}

Laporan Keuangan daerah merupakan suatu ringkasan dari suatu proses pencatatan, suatu ringkasan dari transaksi keuangan yang terjadi selama satu tahun buku yang bersangkutan dan merupakan suatu bentuk pertanggungjawaban pemerintah kepada rakyat atas pengelolaan dana publik baik dari pajak, retribusi atau transaksi lainnya.Pernyataan Standar Akuntansi Pemerintah (SPAP) No.1 menjelaskan definisi laporan keuangan sebagai laporan yang terstruktur mengenai posisi keuangan dan transaksi-transaksi yang dilakukan oleh suatu entitas pelaporan. Laporan keuangan menjadi alat yang digunakan untuk menunjukan capaian kinerja dan pelaksanaan fungsi pertanggungjawaban dalam suatu entitas.

\subsubsection{Tujuan Laporan Keuangan}

Pelaporan keuangan pemerintah seharusnya menyajikan informasi yang bermanfaat bagi para pengguna dalam menilai akuntabilitas dan membuat keputusan baik keputusan ekonomi, sosial, maupun politik dengan:

1. menyediakan informasi tentang sumber, alokasi dan penggunaan sumber daya keuangan.

2. Menyediakan informasi mengenai kecukupan penerimaan periode berjalan untuk membiayai seluruh pengeluaran.

3. Menyediakan informasi mengenai jumlah sumber daya ekonomi yang digunakan dalam kegiatan entitas pelaporan serta hasil-hasil yang telah dicapai.

4. Menyediakan informasi mengenai bagaimana entitas pelaporan mendanai seluruh kegiatannya dan mencukupi kebutuhan kasnya.

5. Menyediakan informasi mengenai posisi keuangan dan kondisi entitas pelaporan berkaitan dengan sumber-sumber penerimaannya, baik jangka pendek maupun jangka panjang, termasuk yang berasal dari pungutan pajak dan pinjaman.

6. Menyediakan informasi mengenai perubahan posisi keuangan entitas pelaporan, apakah mengalami kenaikan atau penurunan, sebagai akibat kegiatan yang dilakukan selama periode pelaporan.

\subsubsection{Karakteristik}

Karakteristik kualitatif laporan keuangan menurut Peraturan Pemerintah No. 71

Tahun 2010 tentang Standar Akuntansi Pemerintahan (SAP) adalah ukuran-ukuran normatif yang perlu diwujudkan dalam informasi akuntansi sehingga dapat memenuhi tujuannya. Keempat karakteristik berikut ini merupakan prasyarat normatif yang diperlukan agar laporan keuangan pemerintah daerah dapat memenuhi kualitas yang dikehendaki

1) Relevan

Laporan keuangan bisa dikatakan relevan apabila informasi yang termuat di dalamnya dapat mempengaruhi keputusan pengguna dengan membantu mereka mengevaluasi peristiwa masa lalu atau masa kini dan memprediksi masa depan serta menegaskan atau mengoreksi hasil evaluasi mereka di masa lalu

\section{2) Andal}

Penggunaan informasi tersebut dapat dicegah Informasi dalam laporan keuangan bebas dari pengertian yang menyesatkan dan kesalahan material, menyajikan setiap fakta secara jujur, serta dapat diverifikasi.

1) Dapat Dibandingkan

Informasi yang termuat dalam laporan keuangan akan lebih berguna jika dapat dibandingkan dengan laporan keuangan periode sebelumnnya atau laporan keuangan entitas pelaporan lain pada umummnya.

2) Dapat Dipahami 
Informasi yang disajikan dalam laporan keuangan dapat dipahami oleh pengguna dan dinyatakan dalam bentuk serta istilah yang disesuaikan dengan batas pemahaman para pengguna.

\subsubsection{Hipotesis penelitian}

Berdasarkan rumusan masalah penelitian yang telah dipaparkan sebelumnya, maka hipotesis dalam penelitian ini adalah :

1. H1 : Diduga Sistem Pengendalian Intern berpengaruh terhadap kualitas laporan keuangan pemerintah daerah

H2 :Diduga Sistem Akuntansi Keuangan Daerah berpengaruh terhadap kualitas laporan keuangan pemerintah daerah

\subsubsection{Penelitian Terdahulu}

1. As Syifa Nurlillah (2014) dalam penelitian yang berjudul Pengaruh Kompetensi Sumberdaya Manusia, Penerapan Sistem Akuntansi Keuangan Daerah (SAKD), Pemanfaatan Teknologi Informasi, dan Sistem Pengendalian Intern Terhadap Kualitas Laporan Keuangan Pemerintah Daerah. Dengan hasil pengujian hipotesis adalah kompetensi SDM, penerapan Sistem Akuntansi Keuangan Daerah, pemanfaatan teknologi informasi dan sistem pengendalian intern pemerintah mempunyai pengaruh positif dan signifikan terhadap kualitas laporan keuangan pemerintah daerah.

2. Erna Sari (2013) dalam penelitian yang berjudul Pengaruh Pemahaman Sistem Akuntansi Pemerintahan dan Penatausahaan Keuangan Daerah Terhadap Kinerja Pengelolaan Keuangan Daerah. Dengan hasil penelitian menunjukan bahwa pemahaman penatausahaan daerah berdampak positif terhadap kinerja pengelolaan keuangan daerah sedangkan pemahaman sistem akuntansi keuangan pemerintah tidak berpengaruh terhadap kinerja pengelolaan keuangan daerah.

\section{METODE PENELITIAN}

\subsection{Jenis penelitian}

Penelitian ini menggunakan pendekatan kuantitatif. Jenis penelitian ini merupakan penelitian explanatory, penelitian explanatory adalah suatu metode penelitian yang bermaksud untuk mendapatkan kejelasan fenomena yang terjadi secara empiris dan berusaha untuk mendapatkan jawaban hubungan kausal antar variabel melalui pengujian hipotesis.

\subsection{Tempat dan Waktu Penelitian}

Penelitian ini dilaksankan pada Badan Pengelola Keuangan dan Aset Daerah Kabupaten Bolaang Mongondow Utara, dimulai pada bulan Oktober sampai selesai.

\subsection{Jenis dan Sumber Data}

Jenis data penelitian yang digunakan dalam penelitian ini adalah jenis data kuantitatif,. Sedangkan sumber data penelitian yang digunakan dalam penelitian ini adalah data primer.

\subsection{Metode pengumpulan data}

Data dikumpulkan melalui metode angket, yaitu dengan menyebarkan kuisioner kepada responden yang merupakan karyawan BPKAD Bolaang Mongondow Utara.

\subsection{Populasi dan sampel}

Populasi yang digunakan dalam penelitian ini adalah BPKAD Bolaang Mongondow Utara. Sampel yang digunakan dalam penelitian ini karyawan yang berada di BPKAD 
BOLMUT yakni sebanyak 30 orang. Pengambilan sampel dalam penelitian ini menggunakan metode purposive sampling.

\subsection{Model dan alat analisis}

Model analisa data yang dipergunakan dalam penelitian ini adalah model analisis regresi linear berganda. Analisis regresi linear berganda adalah hubungan antara dua atau lebih variable independen $(\mathrm{X} 1, \mathrm{X} 2, \ldots \mathrm{Xn})$ dengan variabel dependen (Y). Pada penelitian ini analisis data dilakuakan dengan menggunakan bantuan program aplikasi SPSS Versi 22 for Windows.

Persamaan Linear berganda :

$$
Y^{\prime}=a+\beta_{1} X_{1}+\beta_{2} X_{2}+\beta_{3} X_{3}+e
$$

Keterangan :

$\begin{array}{ll}\mathrm{Y}^{\prime} & =\text { Kualitas Laporan Keuangan Pemerintah } \\ \mathrm{X} 1 & =\text { Sistem Pengendalian Intern } \\ \mathrm{X} 2 & =\text { Sistem Akuntansi Keuangan Daerah } \\ \mathrm{a} & \left.=\text { Konstanta (nilai } \mathrm{Y}^{\prime} \text { apabila } \mathrm{X}_{1}, \mathrm{X}_{2} \ldots \mathrm{X}_{\mathrm{n}}=0\right) \\ \beta & =\text { Koefisien regresi (nilai peningkatan ataupun penurunan) } \\ \mathrm{e} & =\text { Eror }\end{array}$

\subsection{Teknik Analisis}

\subsubsection{Uji validitas}

Uji validitas ini menggambarkan bahwa pertanyaan yang digunakan mampu untuk mengungkapkan sesuatu yang akan diukur (valid). Suatu pertanyaan yang digunakan dikatakan valid jika skor pertanyaan tersebut berkorelasi secara signifikan dengan skor totalnya, batas minimum $r=0,3$ apabila korelasi antara skor butir pertanyaan dengan skor total kurang dari 0,3 maka dinyatakan tidak valid dan harus dibuang atau dikeluarkan.

\subsubsection{Uji reliabilitas}

Uji reliabilitas adalah data untuk mengukur suatu kuisioner yang merupakan indikator dari variabel atau konstruk. Suatu kuisioner dikatakan reliabel atau handal jika jawaban seseorang terhadap pernyataan adalah konsisten atau stabil dari waktu ke waktu. Tinggi rendahnya reliabilitas secara empiris ditujukan oleh suatu angka yang disebut koefisien reliabilitas.

\subsubsection{Uji normalitas}

Salah satu asumsi yang harus dipenuhi dalam melakukan analisis regresi linear baik sederhana maupun berganda adalah data variabel dependen (terikat harus berasal dari populasi yang berdistribusi normal).

\subsubsection{Pengujian hipotesis}

Pengujian hipotesis ini bertujuan untuk menguji ada tidaknya pengaruh dari variabel independen terhadap dependen. Untuk mengetahui diterima atau tidak hipotesis yang diajukan dalam penelitian ini, dilakukan analisis data dengan menggunakan uji $\mathrm{t}$. Uji t digunakan untuk membandingkan antara nilai t $h$ dengan nilai $\mathrm{t}$ dengan kaidah keputusan yaitu jika nilai $\mathrm{t} h \geq \mathrm{t}$, maka Ho ditolak sehingga dapat disimpulkan bahwa variable independen berpengaruh terhadap variable dependen, begitupun sebaliknya. 


\subsubsection{Koefisien determinasi}

Untuk mengukur besarnya proporsi atau presentasi pengaruh variabel independen terhadap variabel dependen maka dilakukan pengujian koefisien determinan. Koefisien determinan berkisar antara nol sampai dengan satu $\left(0 \leq \mathrm{R}^{2} \leq 1\right)$.

\subsection{Definisi Oprasional Variabel}

Variabel penelitian adalah karakeristik dari objek yang akan di observasi, dipelajari, dan ditarik kesimpulan darinya. Adapun variable yang dianalisis dalam penelitian ini sbb :

1. Variabel bebas atau independent variable (X1) yaitu :

Sistem Pengendalian Intern didefinisikan sebagai suatu proses, yang dipengaruhi oleh sumber daya manusia dan sistem teknologi informasi yang dirancang untuk membantu organisasi mencapai suatu tujuan atau objektif tertentu.

2. Variabel bebas atau independent variable (X2) yaitu :

Sistem Akuntansi Keuangan Daerah adalah suatu proses identifikasi, pengukuran, dan pelaporan transaksi ekonomi (keuangan) dari suatu daerah (Provinsi, Kabupaten, Kota) yang dijadikan sebagai informasi dalam pengambilan keputusan ekonomi oleh pihak-pihak yang memerlukan.

3. Variabel terikat atau dependent variable $(\mathrm{Y})$

Kualitas Laporan Keuangan Pemerintah dapat diukur berdasarkan karakterisitik relevan, andal, dapat dibandingkan dan dapat dipahami.

\section{HASIL PENELITIAN DAN PEMBAHASAN}

\subsection{Gambaran umum penelitian}

Pada bab ini peneliti menguraikan hasil survey yang telah diperoleh. Peneliti ingin melihat pengaruh Sistem Pengendalian Intern dan Sistem Akuntansi Keuangan Daerah terhadap kualitas laporan keuangan pemerintah. Variabel independen yang digunakan dalam penelitian ini adalah sebanyak dua variabel yaitu Sistem Pengendalian Intern dan Sistem Akuntansi Keuangan Daerah, sedangkan variabel dependen dalam penelitian ini ialah kualitas laporan keuangan pemerintah.

Responden pada penelitian ini adalah pegawai Badan Pengelolaan Keuangan dan Aset Daerah Bolaang Mongondow Utara, jumlah kuisioner yang disebarkan dalam penelitian ini sebanyak 30 kuisioner. Karakteristik responden yang akan diuraikan berikut meliputi jenis kelamin dan jabatan. Penyebaran kuisioner ini disebarkan ke seluruh Sub Bagian yang ada di BPKAD Bolaang Mongondow Utara.

\subsubsection{Karakteristik Responden Berdasarkan Jenis Kelamin}

\section{Tabel 4.1}

Karakteristik Responden Berdasarkan Jenis Kelamin

\begin{tabular}{|c|c|c|}
\hline Jenis kelamin & Jumlah orang & Presentase (\%) \\
\hline Laki-laki & 14 & 46,7 \\
\hline Wanita & 16 & 53,3 \\
\hline Jumlah & 30 & 100,0 \\
\hline
\end{tabular}

Tabel di atas dapat dilihat bahwa jumlah responden pria sebesar 14 orang atau 46,7 \% sedangkan responden wanita 16 orang atau 53,3 Berdasarkan jenis kelamin responden didominasi oleh wanita. 


\subsubsection{Karakteristik Responden Berdasarkan Jabatan}

Tabel 4.2

Karakteristik Responden Berdasarkan Jabatan

\begin{tabular}{|c|c|c|}
\hline Jabatan & Jumlah & Presentase (\%) \\
\hline Kabid & 4 & 13,3 \\
\hline Kasubbid & 5 & 16,7 \\
\hline Staf & 21 & 70,0 \\
\hline Jumlah & 30 & 100,0 \\
\hline
\end{tabular}

Berdasarkan jabatan dapat dilihat bahwa sebagian besar responden adalah Staf, yaitu 21 Orang atau sebesar 70,0 Persen dari total responden. Sementara kepala Bidang ada sebanyak

4 Orang atau sebanyak 13,3 Persen dan yang terakhir Kepala Sub Bagian ada sebanyak 5

\subsection{Uji Validitas dan Reliabiltas} orang atau sebanyak 13,3 persen..

\subsubsection{Uji Validitas}

Pengujian validitas bertujuan untuk mengetahui apakah pertanyaan yang telah diterapkan dalam kuisioner dapat mengukur variabel yang telah ada. Hasil pengujian variabel Sistem Pengendalian Itern dengan jumlah pertanyaan yang digunakan adalah sebanyak 10 pertanyaan adalah sebagai berikut :

Tabel 4.3

UjiValiditas Sistem Pengendalian Intern

\begin{tabular}{|c|c|c|c|}
\hline Butir Pertanyaan & R Hitung & R Tabel & Keterangan \\
\hline Item_1 &, 505 &, 3610 & Valid \\
\hline Item_2 &, 469 &, 3610 & Valid \\
\hline Item_3 &, 539 &, 3610 & Valid \\
\hline Item_4 &, 691 &, 3610 & Valid \\
\hline Item_5 &, 619 &, 3610 & Valid \\
\hline Item_6 &, 441 &, 3610 & Valid \\
\hline Item_7 &, 434 &, 3610 & Valid \\
\hline Item_8 &, 441 &, 3610 & Valid \\
\hline Item_9 &, 518 &, 3610 & Valid \\
\hline Item_10 &, 468 &, 3610 & Valid \\
\hline
\end{tabular}

Sedangkan untuk uji validitas untuk Sistem Akuntansi Keuangan Daerah dengan jumlah pertanyaan yang digunakan untuk mengukur Sistem Akuntansi Keuangan Daerah adalah sebanyak 10 pertanyaan. Dengan hasil pengujian sebagai berikut :

Tabel 4.4

Uji Validitas Sistem Akuntansi Keuangan Daerah

\begin{tabular}{|c|c|c|c|}
\hline Butir Pertanyaan & R Hitung & R Tabel & Keterangan \\
\hline Item_1 &, 771 &, 3610 & Valid \\
\hline Item_2 &, 792 &, 3610 & Valid \\
\hline Item_3 &, 869 &, 3610 & Valid \\
\hline Item_4 &, 776 &, 3610 & Valid \\
\hline Item_5 &, 772 &, 3610 & Valid \\
\hline Item_6 &, 870 &, 3610 & Valid \\
\hline Item_7 &, 747 &, 3610 & Valid \\
\hline Item_8 &, 854 &, 3610 & Valid \\
\hline Item_9 &, 771 &, 3610 & Valid \\
\hline Item_10 &, 869 &, 3610 & Valid \\
\hline
\end{tabular}

Nilai $r_{\text {tabel }}$ didapatkan dari table dimana $n=30$ dan tingkat signifikan 5\% maka nilai $r_{\text {tabel }}$ sebesar 0,3610. Dengan demikian dari 10 peryataan yang digunakan untuk mengukur pengaruh dari variable Sistem Akuntansi Keuangan Daerah, semua pertanyaan telah memiliki 
$\mathrm{r}_{\text {hitung }}>\mathrm{r}_{\text {tabel }} 0.3610$ sehingga pertanyaan yang digunakan valid. sedangkan untuk hasil pengujian validitas atas kualitas laporan keuangan pemerintah dengan 11 pertanyaan yang digunakan adalah sebagai berikut :

Tabel 4.5

Uji Validitas Kualitas Laporan Keuangan Pemerintah

\begin{tabular}{|c|c|c|c|}
\hline Butir Pertanyaan & R Hitung & R Tabel & Keterangan \\
\hline Item_1 &, 568 &, 3610 & Valid \\
\hline Item_2 &, 756 &, 3610 & Valid \\
\hline Item_3 &, 750 &, 3610 & Valid \\
\hline Item_4 &, 615 &, 3610 & Valid \\
\hline Item_5 &, 671 &, 3610 & Valid \\
\hline Item_6 &, 609 &, 3610 & Valid \\
\hline Item_7 &, 559 &, 3610 & Valid \\
\hline Item_8 &, 529 &, 3610 & Valid \\
\hline Item_9 &, 495 &, 3610 & Valid \\
\hline Item_10 &, 859 &, 3610 & Valid \\
\hline Item_11 &, 633 &, 3610 & Valid \\
\hline
\end{tabular}

Dari hasil uji validitas yang dilakukan terhadap variabel Kualitas Laporan Keuangan Pemerintah dengan 11 pertanyaan, semua pertanyaan telah memiliki nilai $r_{\text {hitung }}>r_{\text {tabel }} 0.3610$ sehingga pertanyaan yang digunakan valid.

Dengan demikian dapat disimpulkan peryataan yang digunakan untuk mengukur pengaruh dari variable $\mathrm{X} 1, \mathrm{X} 2$, dan $\mathrm{Y}$ semua pernyataan telah memiliki $\mathrm{r}_{\text {hitung }}>\mathrm{r}_{\text {tabel }} 0.3610$ sehingga pertanyaan yang digunakan memenuhi uji validitas atau dikatakan valid dan dapat digunakan untuk pengumpulan data penelitian.

\subsubsection{Uji reliabilitas}

Uji reliabilitas merupakan suatu ukuran kestabilan dan konsistensi responden dalam menjawab hal yang berkaitan dengan pertanyaan yang merupakan suatu variabel dan disusun dalam satu bentuk kuisioner. Variabel yang digunakan untuk penelitian dikatakan Reliabel jika Cronbach Alpha memiliki nilai lebih besar dari 0,6. Berikut adalah table hasil dari uji reliabilitas dari hasil pengelolaan data spss versi 22 :

Tabel 4.6

Uji Reliabilitas Sistem Pengendalian Intern

Reliability Statistics
\begin{tabular}{|r|r|}
\hline $\begin{array}{c}\text { Cronbach's } \\
\text { Alpha }\end{array}$ & N of Items \\
\hline .700 & 10 \\
\hline
\end{tabular}

Dari tabel uji reliabilitas diatas dapat diketahui bahwa nilai Cronbach Alpha lebih besar dari nilai 0,6 sehinga pertanyaan yang digunakan memenuhi kriteria reliabel.

Tabel 4.7

Uji reliabilitas Sistem Akuntansi Keuangan Daerah

Reliability Statistics

\begin{tabular}{|r|r|}
\hline $\begin{array}{c}\text { Cronbach's } \\
\text { Alpha }\end{array}$ & N of Items \\
\hline .940 & 10 \\
\hline
\end{tabular}

Dari tabel uji reliabilitas diatas dapat diketahui bahwa nilai Cronbach Alpha lebih besar dari nilai $\mathrm{R}_{\text {tabel }}$ sehinga pertanyaan yang digunakan memenuhi kriteria reliabel. 


\section{Tabel 4.8}

Uji Reliabilitas Kualitas Laporan Keuangan Pemerintah

\section{Reliability Statistics}

\begin{tabular}{|r|r|}
\hline $\begin{array}{c}\text { Cronbach's } \\
\text { Alpha }\end{array}$ & N of Items \\
\hline .844 & 11 \\
\hline
\end{tabular}

Dari tabel uji reliabilitas diatas dapat diketahui bahwa nilai Cronbach Alpha lebih besar dari nilai 0,6 sehinga pertanyaan yang digunakan memenuhi kriteria reliabel.

Keseluruhan uji reliabilitas yang dilakukan menunjukan bahwa Cronbach Alpha lebih besar dari 0,6, dan koefisien reliabilats atas pernyataan-pernyataan pada variable bebas dan variable terikat adalah reliabel, maka dapat disimpulkan bahwa pernyataan tersebut dapat digunakan untuk mengukur variable-variabel bebas dan terikat dengan tingkat konsistensi yang sangat baik.

\subsubsection{Hasil Pengujian Asumsi Klasik}

Sebelum data di analisis lebih lanjut menggunakan analisis regresi linier berganda, data tersebut harus memenuhi syarat-syarat yang dikehendaki dalam analisis regresi. Adapun syarat yang harus dipenuhi dalam regresi linier berganda yang digunakan dalam penelitian ini adalah sebagai berikut:

1. Uji Normalitas

Uji normalitas bertujuan untuk menguji apakah dalam model regresi, variabel terikat dan variabel bebas keduanya mempunyai distribusi normal atau tidak. Model regresi yang baik adalah memiliki distribusi data normal atau mendekati normal. Hasil uji One Sample Kolmogorov Smirnov dapat dilihat pada tabel berikut:

Tabel 4.9

Uji Normalitas

One-Sample Kolmogorov-Smirnov Test

\begin{tabular}{|cc|r|}
\hline & & $\begin{array}{r}\text { Unstandardiz } \\
\text { ed Residual }\end{array}$ \\
\hline Normal Parameters ${ }^{\text {a,b }}$ & Mean & 30 \\
& Std. & .0000000 \\
& Deviation & 2.31148469 \\
Most Extreme & Absolute & .117 \\
Differences & Positive & .106 \\
& Negative & -.117 \\
Test Statistic & .117 \\
Asymp. Sig. (2-tailed) & $.200^{\text {c,d }}$ \\
\hline
\end{tabular}

a. Test distribution is Normal.

b. Calculated from data.

c. Lilliefors Significance Correction.

d. This is a lower bound of the true significance.

Berdasarkan tabel diatas dapat dilihat bahwa nilai Kolmogorov-Smirnov memiliki nilai sebesar 0,117 dan Asymp. Sig. sebesar 0,20 lebih besar dari 0,05, sehingga dapat disimpulkan bahwa data yang digunakan berdistribusi normal. 
Uji normalitas juga dapat dilihat dari gambar Normal P-P Plot pada Gambar 4.1. Kriteria sebuah data berdistribusi normal atau tidak dengan pendekatan Normal P-P Plot dapat dilakukan dengan melihat sebaran titik-titik yang ada pada gambar. Apabila sebaran titik-titik tersebut mendekati atau rapat pada garis lurus (diagonal) maka dikatakan bahwa data (data) residual terdistribusi normal, namun apabila sebaran titik-titik tersebut menjauhi garis maka data tidak terdistribusi normal.

Gambar 4.1

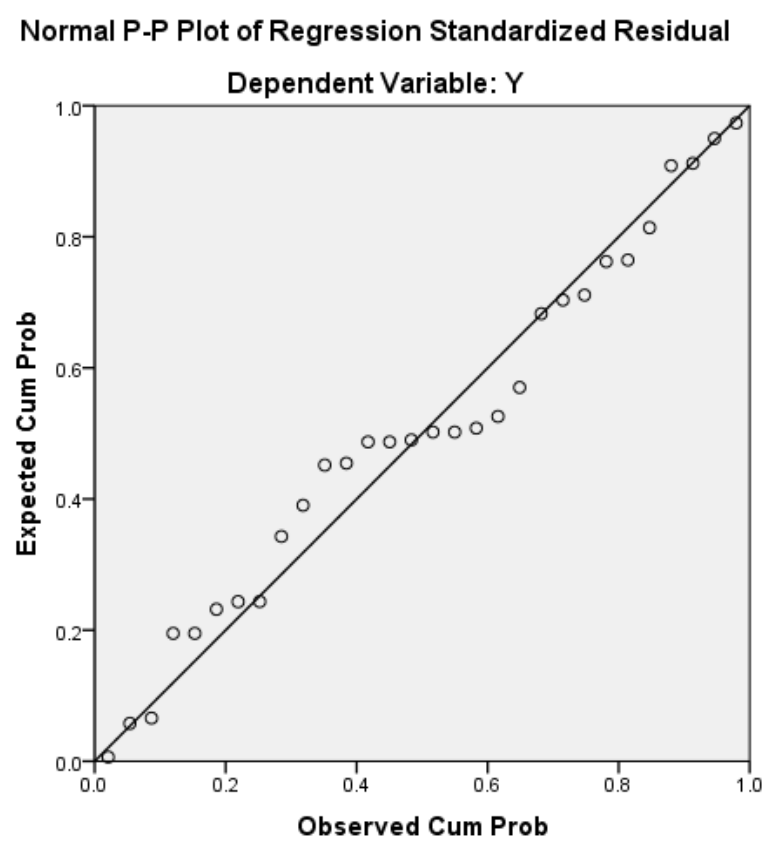

Sebaran titik-titik diatas relatif mendekati garis diagonal, sehingga dapat disimpulkan bahwa data yang digunakan berdistribusi normal. Hal ini sejalan dengan hasil uji KolmogorovSmirnov yang telah dilakukan di atas.

\subsubsection{Analisis Regresi Linear Berganda}

Analisis regresi berganda berfungsi untuk mengetahui pengaruh antara beberapa variabel independen (X1 dan X2) terhadap Variabel dependen (Y). dalam penelitian ini analisis menggunakan bantuan program SPSS sebagai berikut :

\section{Tabel 4.10}

\section{Coefficients $^{\mathrm{a}}$}

\begin{tabular}{|c|c|c|c|c|c|c|}
\hline & \multirow[b]{2}{*}{ Model } & \multicolumn{2}{|c|}{$\begin{array}{c}\text { Unstandardized } \\
\text { Coefficients }\end{array}$} & \multirow{2}{*}{$\begin{array}{l}\text { Standardized } \\
\text { Coefficients } \\
\text { Beta }\end{array}$} & \multirow[b]{2}{*}{$\mathrm{t}$} & \multirow[b]{2}{*}{ Sig. } \\
\hline & & B & Std. Error & & & \\
\hline 1 & (Constant) & 26.628 & 6.323 & & 4.211 & .000 \\
\hline & SPI & -.696 & .206 & -.393 & -3.376 & .002 \\
\hline & SAKD & 1.018 & .116 & 1.023 & 8.784 & .000 \\
\hline
\end{tabular}

a. Dependent Variable: Y

Berdasarkan hasil analisis regresi berganda diatas, maka diperoleh persamaan regresi yang dapat disimpulkan sebagai berikut :

$\mathrm{Y}=26,628+(0,696) \mathrm{X} 1+1,018 \mathrm{X} 2$ 
Konstanta $(\alpha)=26,628$ menunjukan harga konstan, bahwa jika tidak ada variabel Sistem Pengendalian Intern (X1) dan Sistem Akuntansi keuangan daerah yang mempengaruhi kualitas laporan keuangan pemerintah, maka kualitas laporan keuangan pemerintah konstan. Koefisien regresi variabel Sistem Pengendalian Intern $(X 1)=(0,696)$ menunjukan bahwa semakin efektif dan efisien Sistem Pengendalian Intern (X1) yang diterapkan maka akan meningkatkan kualitas laporan keuangan pemerintah dengan anggapan Sistem Akuntansi Keuangan Daerah (X2) tetap/konstan.

Koefisien regresi variabel Sistem Akuntansi Keuangan Daerah $(\mathrm{X} 2)=1,018$ menunjukan bahwa semakin baik penerapan Sistem Akuntansi Keuangan Daerah (X2) yang diterapkan maka akan meningkatkan kualitas laporan keuangan pemerintah dengan anggapan Sistem Pengendalian Intern (X1) tetap/konstan.

\subsubsection{Pengujian Hipotesis}

Uji t digunakan untuk membandingkan antara nilai $\mathrm{t} h$ dengan nilai $\mathrm{t}$ dengan kaidah keputusan yaitu jika nilai $\mathrm{t} h \geq \mathrm{t}$, maka Ho ditolak sehingga dapat disimpulkan bahwa variable independent berpengaruh terhadap variable dependen, begitupun sebaliknya.

Tabel 4.11

Coefficients $^{\mathrm{a}}$

\begin{tabular}{|c|c|c|c|c|c|}
\hline \multirow[b]{2}{*}{ Model } & \multicolumn{2}{|c|}{$\begin{array}{c}\text { Unstandardized } \\
\text { Coefficients }\end{array}$} & \multirow{2}{*}{$\begin{array}{c}\text { Standardized } \\
\text { Coefficients } \\
\text { Beta }\end{array}$} & \multirow[b]{2}{*}{$\mathrm{t}$} & \multirow[b]{2}{*}{ Sig. } \\
\hline & B & Std. Error & & & \\
\hline (Constant) & 26.628 & 6.323 & & 4.211 & .000 \\
\hline SPI & -.696 & .206 & -.393 & -3.376 & .002 \\
\hline SAKD & 1.018 & .116 & 1.023 & 8.784 & .000 \\
\hline
\end{tabular}

a. Dependent Variable: Y

Hasil pengujian Sistem Pengendalian Intern (H1) adalah sebesar 3,376 dengan jumlah sampel sebanyak 30 , sehingga derajat kebebasan $(\mathrm{df})=30-3=27$, sehingga $t_{\text {tabel }}$ dengan $\mathrm{df}=27$ adalah sebesar 2,051 hal ini menunjukan bahwa variabel Sistem Pengendalian Intern memiliki nilai $t_{\text {hitung }} 3,376>t_{\text {tabel }} 2,051$ dengan signifikan sebesar 0,02 lebih kecil dibandingkan probabilitas $(\alpha)$ 0,05. Berdasarkan uji hipotesis diatas maka dapat disimpulkan bahwa Sistem pengendalian intern berpengaruh signifikan terhadap kualitas laporan keuangan pemerintah, sehingga hipotesis pertama (H1) diterima. Sedangkan untuk hasil pengujian Sistem Akuntansi Keuangan Daerah (H2) adalah sebagai berikut :

Hasil pengujian Sistem Akuntansi Keuangan Daerah (H2) adalah sebesar 8,784 dengan jumlah sampel sebanyak 30 , sehingga mendapatkan df $=30-3=27$, sehingga $t_{\text {tabel }}$ dengan $\mathrm{df}=27$ adalah sebesar 2,051 hal ini menunjukan bahwa variabel Sistem Akuntansi Keuangan Daerah memiliki nilai $t_{\text {hitung }} 8,784>t_{\text {tabel }}$ 2,051 dengan signifikan sebesar 0,00 lebih kecil dibandingkan probabilitas $(\alpha)$ 0,05 maka dapat disimpulkan bahwa Sistem Akuntansi Keuangan Daerah berpengaruh signifikan terhadap kualitas laporan keuangan pemerintah, sehingga hipotesis kedua (H2) diterima.

Setelah melakukan uji t peneliti melakukan uji $\mathrm{f}$ dimana uji $\mathrm{f}$ berfungsi untuk mengetahui pengaruh secara simultan antara variabel independen terhadap variabel dependen. 
Tabel 4.12

ANOVA $^{\mathrm{a}}$

\begin{tabular}{|rc|r|r|r|r|r|}
\hline & Model & \multicolumn{1}{|c|}{$\begin{array}{c}\text { Sum of } \\
\text { Squares }\end{array}$} & df & \multicolumn{1}{c|}{$\begin{array}{c}\text { Mean } \\
\text { Square }\end{array}$} & F & \multicolumn{1}{c|}{ Sig. } \\
\hline 1 & Regression & 463.354 & 2 & 231.677 & 40.371 & $.000^{\mathrm{b}}$ \\
& Residual & 154.946 & 27 & 5.739 & & \\
& Total & 618.300 & 29 & & & \\
\hline
\end{tabular}

a. Dependent Variable: Y

b. Predictors: (Constant), SAKD, SPI

Dari hasil pengujian tabel Anova diatas dapat dilihat bahwa nilai $\mathrm{F}_{\text {hitung }}$ 40,371 dimana $F_{\text {tabel }}$ adalah sebesar 3,34, sehingga $F_{\text {hitung }} 40,371>F_{\text {tabel }} 3,34$ dengan tingkat signifikan 0,00 lebih kecil dibandingkan probabilitas $(\alpha)$ 0,05 sehingga Ho ditolak dan $\mathrm{H}_{\mathrm{a}}$ diterima. Dari Uji F diatas dapat ditarik kesimpulan bahwa secara bersamaan Sistem Pengendalian Intern dan Sistem Akuntansi Keuangan Daerah berpengaruh secara simultan terhadap kualitas laporan keuangan pemerintah daerah.

\subsubsection{Koefisien Determinasi}

Koefisien determinasi untuk mengukur besarnya proporsi atau pengaruh variabel independen terhadap variabel dependen. Nilai koefisien determinasi merupakan suatu nilai yang besarnya berkisar antara 0\% - 100\%. Semakin besar nilai koefisien determinasi suatu model regresi menunjukkan bahwa pengaruh dari variabel bebas yang terdapat dalam model terhadap variabel tidak bebasnya juga semakin tinggi. Untuk mengetahui besarnya koefisien determinasi $\left(\mathrm{R}^{2}\right)$ dapat dilihat pada tabel berikut:

Tabel 4.14

Model Summary ${ }^{\mathrm{b}}$

\begin{tabular}{|c|c|r|r|r|}
\hline Model & R & R Square & $\begin{array}{c}\text { Adjusted R } \\
\text { Square }\end{array}$ & $\begin{array}{c}\text { Std. Error of } \\
\text { the Estimate }\end{array}$ \\
\hline 1 & $.866^{\mathrm{a}}$ & .749 & .731 & 2.396 \\
\hline
\end{tabular}

a. Predictors: (Constant), SAKD, SPI

b. Dependent Variable: Y

Tabel di atas menunjukan bahwa besarnya koefisien determinasi atau angka $R$ Square adalah sebesar 0.731 Hal ini berarti besarnya pengaruh kualitas laporan keuangan pemerintah diperoleh presentase sebesar 73,1 \% dan sisanya sebesar 26,9\% (100-73,1) dipengaruhi oleh variabel lain yang tidak diikut sertakan dalam penelitian ini.

\subsection{Pembahasan}

\subsubsection{Sistem Pengendalian Intern berpengaruh terhadap kualitas laporan keuangan pemerintah}

Pengertian Sistem Pengendalian Intern menurut PP No. 60 Tahun 2008 tentang Sistem Pengendalian Intern adalah " Proses yang integral pada tindakan dan kegiatan yang dilakukan secara terus menerus oleh pimpinan dan seluruh pegawai untuk memberikan keyakinan memadai atas kepercayaan tujuan organisasi melalui kegiatan yang efektif dan efisien, keandalan pelaporan keuangan, pengamatan aset Negara, dan ketaatan terhadap peraturan perundang-undangan".

Berdasarkan penelitian yang dilakukan menunjukan bahwa variabel Sistem Pengendalian Intern memilki nilai $t_{\text {hitung }}$ sebesar $-3,376$ dan $t_{\text {tabel }}$ sebesar 2,051, dimana $t_{\text {hitung }}<$ 
$t_{\text {tabel }}$ dengan signifikan sebesar 0,02 lebih besar dari 0,05 sehingga menyatakan bahwa hipotesis pertama $(\mathrm{H} 1)$ diterima dan Ho ditolak. Dengan demikian variabel Sistem Pengendalian Intern berpengaruh negatif dan signifikan terhadap kualitas laporan keuangan pemerintah daerah. Berdasarkan penelitian ini dapat disimpulkan bahwa Sistem Pengendalian Intern yang diterapakan sudah baik, namun belum dijalankan secara efektif dan efisien sehingga menyebabkan kurangnya kualitas laporan keuangan yang dihasilkan.

Penelitian ini sejalan dengan penelitian yang dilakukan oleh Reni Yendrawati yang berjudul : Pengaruh Sistem Pengendalian Intern dan Kapasitas Sumberdaya Manusia Terhadap Kualitas Informasi Laporan Keuangan Dengan Faktor Eksternal Sebagai Variabel Moderating, dengan hasil penelitian menunjukkan bahwa Sistem Pengendalian Intern berpengaruh negatif terhadap kualitas informasi laporan keuangan, kapasitas sumberdaya manusia berpengaruh posifit terhadap kualitas informasi laporan keuangan dan faktor eksternal dapat memoderasi pengaruh Sistem Pengendalian Intern terhadap kualitas informasi laporan keuangan. Sedangkan faktor eksternal tidak dapat memoderasi pengaruh seumberdaya manusia terhadap kualitas informasi laporan keuangan. Penelitian ini juga sejalan dengan penelitian yang dilakukan oleh As Syifa Nurillah yang berjudul : Pengaruh Kompetensi Sumberdaya Manusia, Penerapan Sistem Akuntansi Keuangan Daerah (SAKD), Pemanfaatan Teknologi Informasi, dan Sistem Pengendalian Intern Terhadap Kualitas Laporan Keuangan Pemerintah Daerah, dengan hasil pengujian hipotesis adalah kompetensi SDM, penerapan Sistem Akuntansi Keuangan Daerah, pemanfaatan teknologi informasi dan sistem pengendalian intern pemerintah mempunyai pengaruh positif dan signifikan terhadap kualitas laporan keuangan pemerintah daerah.

\subsubsection{Sistem Akuntansi Keuangan Daerah berpengaruh terhadaap kualitas laporan keuangan pemerintah daerah}

Berdasarkan penelitian yang dilakukan menunjukan bahwa variabel Sistem Akuntansi Keuangan Daerah memilki nilai $t_{\text {hitung }}$ sebesar 5,417 dan $t_{\text {tabel }}$ sebesar 2,051, dimana $t_{\text {hitung }}>t_{\text {tabel }}$ dengan signifikan sebesar 0,00 lebih kecil dari 0,05 sehingga menyatakan bahwa hipotesis pertama (H1) diterima dan Ho ditolak. Dengan demikian variabel Sistem Akuntansi Keuangan Daerah berpengaruh signifikan terhadap kualitas laporan keuangan pemerintah daerah.

Penelitian ini sejalan dengan penelitian Angga Dwi Permadi yang berjudul : Pengaruh Penerapan Sistem Akuntansi Keuangan Pemerintah Terhadap Kualitas Laporan Keuangan Pemerintah Daerah. Hasil penelitian ini menunjukan bahwa Sistem Akuntansi Keuangan Daerah berpengaruh terhadap kualitas laporan keuangan daerah. Dan penelitian yang dilakukan oleh Emilda Ihsanti yang berjudul : Pengaruh Kompetensi Sumber Daya Manusia dan Penerapan Sistem Akuntansi Keuangan Daerah Terhadap Kualitas Laporan Keuangan Daerah dengan hasil penelitian Hasil penelitian ini menunjukan bahwa : (1) terdapat pengaruh positif dan signifikan antara pemahaman sistem akuntansi keuangan daerah terhadap kualitas laporan keuangan daerah (2) tidak terdapat pengaruh positif dan signifikan antara pemahaman penatausahaan keuangan daerah terhadap kualitas laporan keuangan daerah. Dan sejalan dengan penelitian Ni Made Rika Krisna berjudul : Pengaruh Pemahaman Sistem Akuntansi Keuangan Daerah dan Pengelolaan Keuangan Daerah terhadap Kualitas Informasi Laporan Keuangan Pemerintah daerah. Dengan hasil penelitian Hasil penelitian menunjukan baik secara parsial maupun simultan Pemahaman Sistem Akuntansi Keuangan Daerah dan Pengelolaan Keuangan Daerah berpengaruh positif dan signifikan terhadap kualitas informasi laporan keuangan pemerintah.

Pemerintah diwajibkan menyusun laporan keuangan sesuai dengan Sistem Akuntansi Keuangan Daerah yang telah diatur oleh pemerintah daerah yang berpatokan pada Standar Akuntansi Pemeritah dalam Undang-undang yang bersifat mengikat seluruh pemerintah 
daerah. sehingga dapat disimpulkan bahwa penerapan Sistem Akuntansi Keuangan Daerah yang baik dan benar berpengaruh terhadap kualitas laporan keuangan pemerintah.

\section{KESIMPULAN DAN SARAN}

\subsection{Kesimpulan}

Variabel independen yang digunakan dalam penelitian ini adalah Sistem Pengendalian Intern (X1) dan Sistem Akuntansi Keuangan Daerah (X2), sedangkan variabel dependen yang digunakan adalah kualitas laporan keuagan pemerintah.

1. Berdasarkan hasil penelitian yang telah dilakukan membuktikan bahwa Sistem Pengendalian Itern berpengaruh negative signifikan terhadap kualitas laporan keuangan pemerintah. Hasil penelitian ini berarti sistem pengendalian intern pada BPKAD Bolaang Mongondow utara yang telah dijalankan sudah baik namun dalam penerapannya belum efektif dan efisien sehingga berpengaruh terhadap kurangnnya kualitas laporan keuangan pemerintah.

2. Berdasarkan hasil penelitian penerapan Sistem Akuntansi Keuangan Daerah berpengaruh positif terhadap kualitas laporan keuangan pemerintah. Hasil penelitian ini berarti bahwa pegawai bagian akuntansi/keuangan yang berada di BPAKD Bolaang Mongondow utara sudah memahami prosedur akuntansi sampai dengan menjadi laporan keuangan sehingga memungkinkan untuk memperoleh kualitas laporan keuangan yang baik.

\subsection{Saran}

Dari hasil penelitian ini penulis menyarankan sebagai berikut :

1. Pemerintah Kab Bolaang Mongondow, khususnya di BPKAD Bolaang Mongodow Utara diharapkan dapat meningkatkan perekrutan/penambahan pegawai di bidang akuntansi/keuangan yang memiliki latar belakang pendidikan akuntansi.

2. Untuk sering mengadakan pendidikan dan pelatihan terhadap software akuntansi ataupun yang digunakan dalam pekerjaanya.

3. Meningkatkan pengawasan untuk menjamin pelaksanaan SPI dapat berjalan dengan baik, serta komitmen pimpinan dan karyawan-karyawan yang ada di BKPAD Bolaang Mongondow utara dalam Sistem Pengendalian Intern, dengan komitmen suatu keputusan yang akan diambil terkait perbaikan pengendalian intern, prosedur dan aturan akan dilaksnanakan untuk mencapai kesuksesan suatu organisasi/instansi pemerintah.

4. Untuk penelitian selanjutnya, supaya dapat mempertimbangkan atau menambahkan variabel-variabel lain yang mempengaruhi Kualitas laporan Keuangan Pemerintah yang belum diteliti dalam penelitian ini.

\section{DAFTAR PUSTAKA}

Abdul, Halim dkk. 2012. Akuntansi Sektor Publik, Akuntansi Keuangan Daerah. Edisi Keempat. Salemba Empat. Jakarta.

Commite Of Sponsoring Organization Ot The Treadway Commission. 2013. Internal Control - Integrated Framework. WWW.coso.org

Halim, Abdul dkk. 2012. Akuntansi Sektor Publik, Akuntansi Keuangan Daerah. Edisi Keempat. Salemba Empat. Jakarta.

Keputusan Menteri Keuangan Nomor 355/KMK.07/2001 tentang Pedoman Sistem Akuntansi Keuangan Daerah.

Mulyadi. 2013. Sistem Akuntansi, Edisi Ketiga, Cetakan Keempat, Salemba Empat. Jakarta. 
Nurillah, As Syifa. 2014. Pengaruh Kompetensi Sumber Daya Manusia, Penerapan Sistem Akuntansi Keuangan Daerah (SAKD), Pemanfaatan Teknologi Informasi, dan Sistem Pengendalian Intern terhadap Kualitas Laporan Keuangan Pemerintah Daerah. Skripsi. Fakultas Ekonomika dan Bisnis Universitas Diponegoro Semarang.Pemendagri No. 64 Tahun 2103 tentang Penerapan Standar Akuntansi Pemerintah Berbasis Akrual pada Pemerintah Daerah. Jakarta.

Peraturan Pemerintah No. 71 Tahun 2010 tentang Standar Akuntansi Pemerintah. Jakarta.

Peraturan Pemerintah No.60 Tahun 2008 tentang Sistem Pengendalian Intern Pemerintah.

Pemendagri Nomor 13 Tahun 2006 tentang Pengelolaan Keuangan Daerah.

PemendagriNomor 59 Tahun 2007 tentang Perubahan Atas Pemendagri Nomor 13 Tahun 2006 tentang Pengelolaan Keuangan Daerah.

Sari, Erna dkk. 2013. Pengaruh Pemahaman Sistem Akuntansi Pemerintahan dan Penatausahaan Keuangan Daerah Terhadap Kinerja Pengelolaan Keuangan Daerah. Jurnal Ekonomi. Universitas Bengkulu.

Sugiyono, 2016. Metodologi Penelitian Kuantitatif, Kualitatif dan R\&D. Alfabeta. Bandung 